DOI: http://dx.doi.org/10.33846/hn40102

http://heanoti.com/index.php/hn

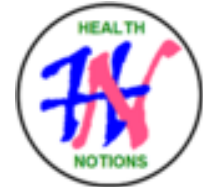

RESEARCH ARTICLE

URL of this article: http://heanoti.com/index.php/hn/article/view/hn40102

\title{
The Effect of Pesticides Usage Behaviour on General Health Conditions of Farmer in Jember Regency, Indonesia
}

\author{
Salim $^{1}$, Erma Sulistyaningsih $^{2(\mathrm{CA})}$, Ristya Widi Endah Yani ${ }^{3}$ \\ ${ }^{1}$ Postgraduate Program of Public Health Science, Universitas Jember, Indonesia; \\ salimsalam895@yahoo.com \\ ${ }^{2(\mathrm{CA})}$ Faculty of Medicine, Universitas Jember, Indonesia; sulistyaningsih.fk@unej.ac.id (Corresponding \\ Author) \\ ${ }^{3}$ Faculty of Dentistry, Universitas Jember, Indonesia; ristya_widi@unej.ac.id
}

\begin{abstract}
The agricultural sector remains an important sector in Indonesia's economic development, and pesticides have been essential in agricultural practice to protect crops and increase crop production. However, pesticides can cause a negative impact on health as well as environmental. The purpose of this study was to determine the effect of pesticides usage behavior on farmers' general health conditions. This was an observational analytic study with cross sectional design. The respondent was 377 farmers selected by cluster sampling. The variable of knowledge, attitude and practice were analysed. Data analysis showed that there was a significant effect on the level of knowledge on the farmers' general health conditions with a p-value of 0.001 . As much as $47.2 \%$ of respondents had a low level of knowledge about the use of pesticides. The attitude influenced the general health conditions of farmers with p-value of 0,000 . As much as $52.5 \%$ of respondents had a positive attitude related to pesticides and $47.5 \%$ had a negative attitude concerning pesticides usage. The variable of practice on the use of pesticides significantly affected the general health conditions of farmers with a p-value of 0.003 . And as much as $17.0 \%$ respondents showed a bad practice, $65.5 \%$ moderate practice and $17.5 \%$ good practice on pesticides.
\end{abstract}

Keywords: attitude; health; knowledge; practice; pesticide

\section{INTRODUCTION}

\section{Background}

The agricultural sector has a strategic role in the structure of national economic development. This sector is important to boost Indonesia's features in the world. Based on the National Central Statistics (BPS), the agriculture sector continued to make a positive contribution to the Indonesian economy in the second quarter, according to BPS, Indonesia's gross domestic product (GDP) amounted to Rp 3,683.9 trillions ${ }^{(1)}$. The Indonesian National Long Term Development Plan phase 3 2015-2019 reported that the agricultural sector remains an important sector in national economic development ${ }^{(2)}$. Nevertheless, Indonesia's agricultural development has not been able to show maximum results, especially in terms of the welfare of farmers and their contribution to national income. Agricultural development in Indonesia is important. There are several things that underlie the important of the agricultural development in Indonesia, such as the large and diversity of natural resources and its support to the national income, the contribution to the national economic growth, the large number of Indonesian population who depend their lives on the agricultural sector ${ }^{(1,2)}$. 
Most of the area of Jember Regency is lowland, with an average land height of 83 meters above sea level and is a fairly fertile area and is very suitable for the development of agricultural and plantation commodities $^{(3)}$. Jember Regency is also famous for its tobacco products. The data in 2011 reported that the amount of tobacco production in Jember was 176,239.65 quintals ${ }^{(4,5)}$.

Agricultural sector is commonly used pesticides. The farmers use pesticides to protect their crop as well as increase the crop production ${ }^{(6)}$. There are an increasing trend of the use of pesticides worldwide. The number and types of pesticides release to the market is increase ${ }^{(7)}$. Several studies have reported that pesticides have an effect on human health and environment ${ }^{(8,9)}$. However, the use of pesticides is unavoidable, especially in low income countries.

\section{Purpose}

The purpose of the study was to assess the effect of the behaviour on the use of pesticides on the general health conditions of the farmer in the small district in Jember, Indonesia.

\section{METHODS}

The study was observational study with a cross sectional design. This research was conducted in Kalisat District, Jember Regency, Indonesia. There were 20.040 farmers in the district. The sample in this study was 377 farmers who met the inclusion and exclusion criteria, selected by cluster sampling technique and included into the study after signing an informed consent. The data needed in this study were primary data and secondary data. Data was collected by questionnaires. The data of general health conditions was general appearance, blood pressure, pulse, body tempereature, respiratory frequency, and body mass index (BMI) and measured by digital tensimeters, scales, watches, stature meters and thermometers. Data processing included editing, coding, data entry, and tabulating. Data was analysed using ordinal regression test.

\section{RESULTS}

\section{Characteristics of Farmer in Kalisat District, Jember Regency}

Table 1. Distribution of the farmer's characteristics in Kalisat District, Jember Regency

\begin{tabular}{|c|c|c|c|}
\hline Characteristics of respondents & Classification & Frequency & Percentage \\
\hline Gender & Male & 377 & 100 \\
\hline \multirow[t]{5}{*}{ Age (Year) } & $21-30$ & 44 & 11.7 \\
\hline & $31-40$ & 94 & 24.9 \\
\hline & $41-50$ & 130 & 34.5 \\
\hline & $>50$ & 109 & 28.9 \\
\hline & Total & 377 & 100 \\
\hline \multirow[t]{5}{*}{ Education } & No school & 93 & 24.7 \\
\hline & Elementary school & 167 & 44.3 \\
\hline & Junior high school & 52 & 13.8 \\
\hline & Senior high school & 65 & 17.2 \\
\hline & Total & 377 & 100 \\
\hline \multirow[t]{5}{*}{ Agricultural land } & Their own & 112 & 29.7 \\
\hline & Renting & 32 & 8.5 \\
\hline & Profit sharing & 177 & 46.9 \\
\hline & Working for other people & 56 & 14.9 \\
\hline & Total & 377 & 100 \\
\hline \multirow{5}{*}{$\begin{array}{l}\text { Pesticide usage duration } \\
\text { (year) }\end{array}$} & $5-10$ & 93 & 24.7 \\
\hline & $11-20$ & 89 & 23.6 \\
\hline & $21-30$ & 84 & 22.3 \\
\hline & $>30$ & 111 & 29.4 \\
\hline & Total & 377 & 100 \\
\hline
\end{tabular}


The table 1 revealed that the age of 41-50 years is the commonly age group of the farmer, as many as 130 person or $34.5 \%$. The education level characteristic showed that most respondent had an elementary school level, i.e. 167 respondents $(44.3 \%)$. The majority of respondents were profit sharing type, 177 persons or $46.9 \%$. And mostly had a more than 30 years using of pesticeides, 111 persons $(29.4 \%)$.

\section{Distribution of General Health Conditions of Farmers}

After measurements of blood pressure, pulse, body temperature, respiratory frequency and BMI, it was found that the overall general health conditions of farmers in Kalisat, Jember majority belonged to moderate health conditions, as many as 277 persons or $73.5 \%$. And as many as 55 respondents (14.6\%) were in good health conditions and the rest 45 respondents or $11.9 \%$, were in poor health conditions, as shown in Table 2.

Table 2. Overall distribution of general health conditions of farmers in Kalisat District, Jember Regency

\begin{tabular}{cccc}
\hline Variables & Category & Frequency & Percentage \\
\hline General health conditions & Good & 55 & 14.6 \\
& Moderate & 277 & 73.5 \\
& Poor & 45 & 11.9 \\
\hline Total & & 377 & 100 \\
\hline
\end{tabular}

Distribution of General Health Conditions and Knowledge, Attitude, and Practice on the Use of Pesticides

The study also reported the distribution of the farmer's general health conditions and the association with the knowledge, attitude, and practice, as shown in Table 3, Table 4, and Table 5. Majority of farmers had a low knowledge (47.2\%) with moderate general health conditions $(35.3 \%)$, as shown in Table 3.

Table 3. Cross-tabulation of general health conditions and knowledge on the use of pesticides in Kalisat District, Jember Regency

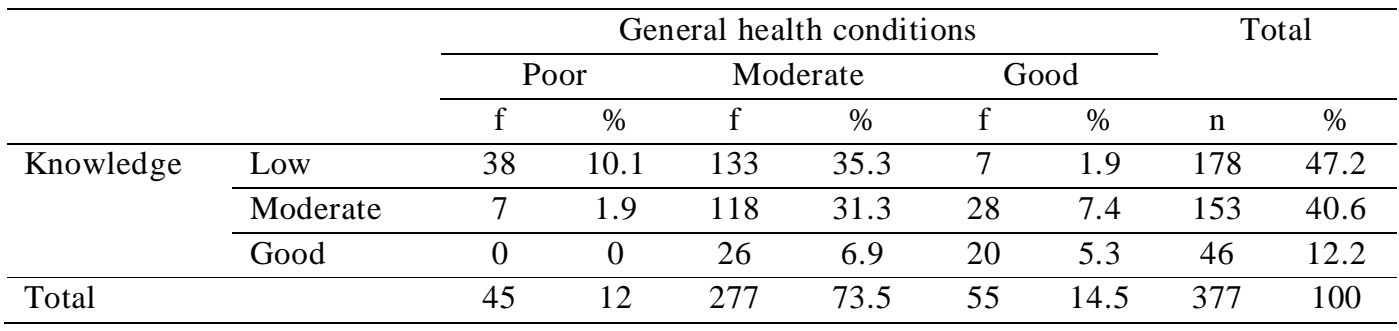

Table 4. Cross-tabulation of general health conditions and attitude on the use of pesticides in Kalisat District, Jember Regency

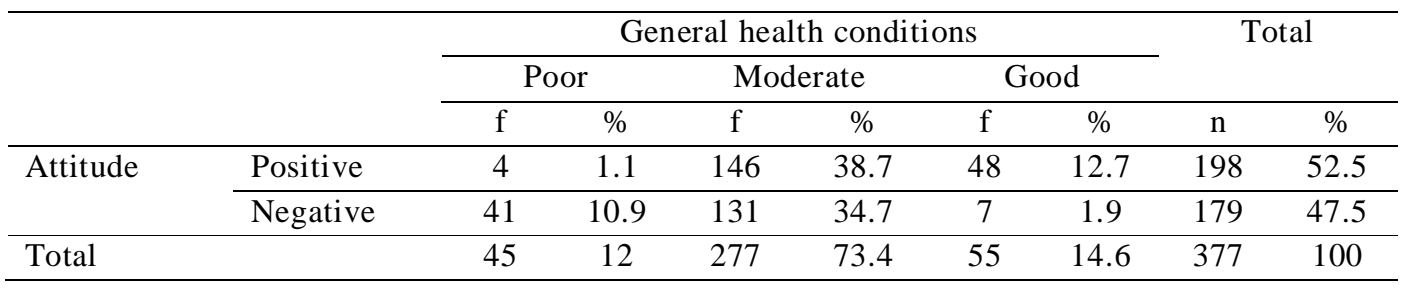


Table 4 showed that more than half respondents $(52.5 \%)$ had a positive attitude on the use of pesticides. And majority of respondents had moderate general health conditions (38.7\%). When we compare with the respondents with negative attitude on pesticides, they showed similar condition, meaning that majority respondents with negative attitude had moderate general health conditions.

Table 5. Cross-tabulation of general health conditions and practice on the use of pesticides in Kalisat District, Jember Regency

\begin{tabular}{|c|c|c|c|c|c|c|c|c|c|}
\hline & \multicolumn{6}{|c|}{ General health conditions } & \multicolumn{2}{|c|}{ Total } \\
\hline & & \multicolumn{2}{|c|}{ Poor } & \multicolumn{2}{|c|}{ Moderate } & \multicolumn{2}{|c|}{ Good } & \multirow[b]{2}{*}{$\mathrm{n}$} & \multirow[b]{2}{*}{$\%$} \\
\hline & & $\mathrm{f}$ & $\%$ & $\mathrm{f}$ & $\%$ & $\mathrm{f}$ & $\%$ & & \\
\hline \multirow[t]{3}{*}{ Practice } & $\mathrm{Bad}$ & 19 & 5.0 & 41 & 10.9 & 4 & 1.1 & 64 & 17.0 \\
\hline & Moderate & 24 & 6.4 & 197 & 52.3 & 26 & 6.9 & 247 & 65.5 \\
\hline & Good & 2 & 0.5 & 39 & 10.3 & 25 & 6.6 & 66 & 17.5 \\
\hline Total & & 45 & 11.9 & 277 & 73.5 & 55 & 14.6 & 377 & 100 \\
\hline
\end{tabular}

Table 5 revealed that majority of repondents had moderate practice on pesticides and also moderate general health conditions $(52.3 \%)$. And only $0.5 \%$ with good practice on pesticides had poor general health conditions.

\section{Parallel Lines Test}

The tabel 6 showed that the Parallel lines test resulted p-value of 0.375 , indicated that the selection of the logit link function models was appropriate.

Table 6. Suitability test model

\begin{tabular}{ccc}
\hline Parallel lines test & $-2 \log$ likelihood & Sig. \\
\hline Null hypothesis & 75.561 & \\
\hline General & 70.212 & 0.375 \\
\hline
\end{tabular}

\section{Significance Test Model}

Tabel 7. Model fitting information

\begin{tabular}{ccc}
\hline Model & $-2 \log$ likelihood & Sig. \\
\hline Intercept only & 176.214 & \\
\hline Final & 75.561 & 0.000 \\
\hline
\end{tabular}

The $\log 2$ likelihood value is used to assess the suitability of the model in ordinal regression analysis. The table 7 revealed that the model significance test was 0,000 , the likelihood value (without predictor variables) was 176.214 and the result of $-2 \log$ likelihood (with predictor variables) was 75,561 meaning that there was a decrease in the value of -2 likelihood. Both of these results indicate that the model is fit to the data.

\section{Goodness of Fit Test}

The table 8 showed the goodness test analysis. It showed that the Pearson value wa 0.266 and the deviance wa 0.347 , meaning that the model is appropriate. Thus, it can be concluded that the model used in this study is suitable. 
Table 8. Goodness of fit test

\begin{tabular}{ccc}
\hline & Chi-square & Sig. \\
\hline Pearson & 31.131 & 0.266 \\
\hline Deviance & 29.286 & 0.347 \\
\hline
\end{tabular}

\section{Model Determination Coefficient}

Table 9. Pseudo R-square

\begin{tabular}{cc}
\hline Cox and Snell & 0.234 \\
\hline Nagelkerke & 0.300 \\
\hline McFadden & 175 \\
\hline
\end{tabular}

The pseudo R-square test resulted the McFadden determination coefficient was 0.175 and the determination coefficient of Cox and Snell was 0.234 and the Nagelkerke was 0.300 or $30 \%$, as shown in Table 9. It indicated that the independent variable is able to explain the dependent variable by $30 \%$.

\section{Estimate Parameter Test}

Table 10. Partial test

\begin{tabular}{ccc}
\hline Variables & Estimate & Sig \\
\hline Knowledge & -1.667 & 0.001 \\
Attitude & 1.470 & 0.000 \\
Practice & -1.379 & 0.003 \\
\hline
\end{tabular}

The partial test found that the variables of knowledge, attitude and practice have a significant influence on the general health conditions of farmers, as revealed by the significance value of the knowledge variable $(0.001)$, the attitude variable $(0.000)$ and the action variable $(0.003)$, meaning that there is an influence of the pesticides usage behaviour on the general health conditions of farmers in Kalisat District, Jember Regency.

\section{DISCUSSION}

As many as 377 respondents in this study were male, because in this district only men who apply pesticides. Study reported that male farmers are more at risk of pesticide poisoning than female farmers because male farmers tend to have lower cholesterol levels compared to female farmers. Majority of the respondents were at the age of 41-50 years. This result is in accordance to other study which reported a decrease of the number of young farmer in many areas due to several reasons, and the average age of farmers are being increased. The older the farmers, the more likely they got a higher exposure to pesticides, this is due to decreased metabolic function in the body and results in decreased blood cholinestrase activity, which will facilitate the occurrence of pesticides poisoning ${ }^{(10)}$. Most respondents of the study only completed the elementary school. It is known that one of the factors influencing knowledge is the level of education, a low level of education will cause difficulty to understand information. In this research, the low level of education will resulted in low knowledge about pesticides, which further impact on the practice of pesticides usage ${ }^{(11)}$. Majority of respondents already used pesticides more than 30 years. The longer a person becomes a farmer, the more the possibility of contact with pesticides ${ }^{(12)}$. A person who has been exposed to pesticides for years is more at risk of being compromised and cause chronic illness.

General health conditions of farmers in this research was determined by measuring blood pressure, pulse, body temperature, respiratory frequency and body mass index. The assessment showed that $14.6 \%$ of farmers had good general health conditions, $73.5 \%$ had moderate general health conditions and $11.9 \%$ had poor general health conditions. Many factors can affect a person's health conditions such 
as environment, behavior, health services and heredity. Health behavior is divided into 3 domains, namely health knowledge, attitude and practice ${ }^{(13)}$. The study found that knowledge, attitude, and practice on the use of pesticide had a significant effect on the farmer's general health conditions with the $\mathrm{p}$ value of $0.001,0.000$, and 0.003 , respectively. Majority of farmers had low knowledge on pesticides, although most of them had a moderate general health conditions. But, there was no farmer with good knowledge had bad general health conditions (Table 3). The low level of knowledge as well as low education level will resulted unawareness of the danger of pesticides both for health and environment, this condition is the risk for general health.

Table 10 showed that there is a significant influence of each variable (knowledge, attitude, and practice) on the general health conditions of farmers. The knowledge predictor variable was $-1,667$ with p-value of 0.001. Majority respodents had a low level of knowledge on the use of pesticides, which cause a risky behavior on pesticides used and further resulted in low level of general health conditions $^{(14)}$.

The study found that majority of respondents had a positive attitude on pesticides use and had moderate general health conditions, as shown in Table 4 . There were only 4 farmers $(1.1 \%)$ with positive attitude showed poor general health conditions. Data analysis showed the correlation between attitude on pesticides use and the general helath conditions $(\mathrm{p}=0.000)$, as shown in table 10. Positive attitude on pesticides use means that the farmers already aware with the benefit of good taking care on pesticides, this is a positive effect on the general health conditions.

Table 10 also represented the significant influence of attitude variable about the use of pesticides on the general health conditions of farmers. It showed an estimated value of 1.470 with p-value of 0.000 . The result indicated that the negative attitude of farmers about the use of pesticides will adversely affect general health conditions, and vice versa. The farmer who had a positively attitute to the use of pesticides will likely to take a positive practice related to the use of pesticides, which further resulted in good general health conditions. The factors that influence attitude including personal experience, information from others who are considered important person, socio-cultural environment, mass media, educational institutions and religious institutions and social factors ${ }^{(15)}$. The more positive information and objects that are known, the more positive attitude will be conduct ${ }^{(13)}$. The research found that the majority respondents had a negatively attitude on the use of pesticides, this was possibly due to the low level of knowledge. Humans are not born with certain views or feelings, but are shaped throughout their development. Attitude is readiness or willingness to act and is not an implementation of certain motives, it is not yet an act or activity but is a predisposition to an action, that attitude is still a closed reactionopen reaction. Attitude is readiness to react to objects in a certain environment as an appreciation of the object $^{(14)}$.

The data on practice on the use of pesticides showed that majority respondents had moderate practice and moderate general health conditions $(52.3 \%)$, as shown in table 5. And only $0.5 \%$ of respondents who had good practice had poor general health conditions. The practice on the use of pesticides significantly affects the farmer's general health conditions $(p=0.003)$, as shown in table 10 . Many factors play a role on the practice of the pesticides use, including knowledge, awareness, facilities, and also culture. The study found that the farmer's practice on the use of pesticides is unfavorable, because they have a low level of knowledge on the danger of pesticides for health as well as environment. Furthermore, the farmers also have low economic status which resulted a limited an adequate facilities to conduct a safety practice on pesticides. The level of knowledge is a predisposing factor of behavior, if a persons have a high level of knowledge, they will have a good behavior related to health, and vice versa ${ }^{(14)}$.

The predictor variable practice on the use of pesticides showed a significant effect on the general health conditions of farmers, as shown in Table 8, with estimated value of -1.379 and p-value of 0.003 . Majority of farmers had a moderate practice on the use of pesticides, but there were farmers who showed a bad practice on the use of pesticides, such as the pesticides storing, pesticides mixing, spraying, the use of personal protective equipment and handling of pesticide containers. Many factors affect this, for example when mixing pesticides, farmers do not wear gloves because they assume that pesticides cannot enter through the skin or palms. Some farmers store their pesticides in the house, near the kitchen. Thus, are risky for farmers and family members because it is well accessible. Some farmers also did not wash the clothes separately for pesticides clothes and not. All practices were conducted due to lack of information related to the pesticides and the effect ${ }^{(16,17)}$.

Several factors affects the general health conditions of farmers including knowledge, economic status, and facilites related to the use of pesticides. Those factors have a contribution on the use of personal protective equipments (PPE) during pesticides application, but there is also factors contributing on the use of PPE including comfortability of the PPE such as gloves, boots and mask. Thus, it needs further approach to increase the use of PPE in farmers while pesticides application by increasing 
knowledge and understanding on pesticides in order to minimize the negative effect of pesticides and increase the general health conditions of farmers ${ }^{(18,19)}$.

\section{CONCLUSION}

Based on the results of the study it can be concluded that there is a significant effect of the behavior (knowledge, attitude, practice) in the use of pesticides on the general health conditions of farmers in Kalisat, Jember Regency. The low level of knowledge of farmers on pesticides affects the attitudes and practices of farmers about the use of pesticides.

\section{REFERENCES}

1. BPS. Central Bureau of Statistics (Badan Pusat Statistik) [Internet]. 2018 [cited 2018 Sep 26]. Available from: https://www.bps.go.id/pressrelease/2018/08/06/1521/ekonomi-indonesia-triwulanii-2018-tumbuh-5-27-persen.html

2. Ministry of Agriculture RI. National Medium-Term Development Plan (RPJMN) phase III of 2015 2019 (Rencana pembangunan jangka menengah nasional (RPJMN) tahap III, tahun 2015-2019). Jakarta: Ministry of Agriculture RI; 2016.

3. BPS Jatim. Central Bureau of Statistics of East Java (Badan Pusat Statistik Jawa Timur) [Internet]. 2016 [cited 2018 May 26]. Available from: https://jatim.bps.go.id/statictable/2017/09/27/629/luaslahan-sawah-menurut-kabupaten-kota-dan-jenis-pengairan-di-provinsi-jawa-timur-ha-2016.html

4. BPS Jember. Jember Regency in numbers (Kabupaten Jember dalam angka). Jember: BPS Jember; 2018.

5. BPS Jember. Kalisat Sub-district in numbers (Kecamatan kalisat dalam angka). Jember: BPS Jember; 2018.

6. Mansour SA. Pesticide exposure- Egyptian scene. Toxicology. 2004;198:91-95.

7. Issa Y, Sham'a FA, ijem K, Bjertness E, Kristensen P. Pesticide use and opportunities of exposure among farmers and their families: cross-sectional studies 1998-2006 from Hebron governorate, occupied Palestinian territory. Environ Health. 2010;9:63.

8. Ntow WJ, Gijzen HJ, Kelderman P, Drechsel P. Farmer perceptions and pesticide use practices in vegetable production in Ghana. Pest Manag Sci. 2006;62:356-365.

9. Clarke EE, Levy LS, Spurgeon A, Calvert IA. The problems associated with pesticide use by irrigation workers in Ghana. Occup. Med (Lond). 1997;47:301-308.

10. Syahfriayani R. Description of knowledge, attitudes and actions of shallot farmers in the use of pesticides with the incidence of poisoning in farmers in the Kersana sub-district of Brebes Regency (Gambaran pengetahuan, sikap dan tindakan petani bawang merah dalam penggunaan pestisida dengan kejadian keracunan pada petani di Kecamatan Kersana Kabupaten Brebes). Semarang: UNNES; 2015.

11. Sularti. The level of knowledge of the dangers of pesticides and the habit of using personal protective equipment can be seen from the appearance of signs and symptoms of poisoning in farmer groups in karanganyar (Tingkat pengetahuan bahaya pestisida dan kebiasaan pemakaian alat pelindung diri dilihat dari munculnya tanda dan gejala keracunan pada kelompok tani di Karanganyar). Surakarta: UMS; 2012.

12. Yuantari C. Gap analysis of farmers' knowledge and practices in using pesticides (Gap analisis pengetahuan dan praktik petani dalam menggunakan pestisida). Semarang: Udinus; 2013.

13. Notoatmodjo S. Health beharior science (Ilmu perilaku kesehatan). Jakarta: Rineka Cipta; 2014.

14. Luthviatin N, Zulkarnain E, Istija E, Rokhmah D. Fundamentals of health promotion \& behavioral science (Dasar-dasar promosi kesehatan \& ilmu perilaku). Jember: UNEJ; 2012.

15. Azwar S. Human Attitudes, Theories and Measurements (Sikap Manusia, Teori dan Pengukurannya). Jakarta: Pustaka Pelajar; 2007.

16. Bassam FA, Mosalami J. Pesticides Usage, Perceptions, Practices and Health Effects among Farmers in North Gaza, Palestine. Indian J Applied Res. 2014;4:6.

17. Lekei EE, Ngowi AV, London L. Farmers' knowledge, practices and injuries associated with pesticide exposure in rural farming villages in Tanzania. BMC Public Health. 2014;14:389.

18. Jallow MFA, Awadh DG, Albaho MS, Devi VY, Thomas BM. Pesticide knowledge and safety practices among farm workers In Kuwait. Int J Environ Res Public Health. 2017;14:340. 
19. Oesterlund AH, Thomsen JF, Sekimpi DK, Maziina J, Rachael A, Jors E. Pesticide knowledge, practice and attitude and how it affects the health of small-scale farmers in Uganda: a crosssectional study. African Health Sci. 2014;14:420-433. 